\title{
Application of SSRT to estimate the effect of corrosive medium on the liability of X70 pipe steel to stress corrosion cracking
}

\author{
V. E. Ignatenko, ${ }^{1}$ Yu. I. Kuznetsov, ${ }^{1}$ A. B. Arabei, ${ }^{2}$ R. V. Igoshin, ${ }^{1}$ \\ R. I. Bogdanov ${ }^{1}$ and A. I. Marshakov ${ }^{1 *}$ \\ ${ }^{1}$ A. N. Frumkin Institute of Physical Chemistry and Electrochemistry, Russian Academy \\ of Sciences, Leninskii pr. 31, Moscow, 119071 Russian Federation \\ ${ }^{2}$ Open Joint-Stock Company "Gazprom”, ul. Nametkina 16, Moscow, \\ 117997 Russian Federation \\ *E-mail: mar@ipc.rssi.ru
}

\begin{abstract}
The slow strain rate test was used to study the effect of a number of corrosive soil electrolyte components and corrosion inhibitors on the liability of pipe steel X70 to stress corrosion cracking in weakly acidic and neutral media simulating the electrolyte under delaminated coatings on underground pipelines. The electrochemical behavior of X70 pipe steel in the presence of some corrosion inhibitors was studied. It was shown that inhibitors of metal anodic dissolution can considerably improve the cracking resistance of pipe steel.
\end{abstract}

Key words: stress corrosion cracking, underground pipelines, pipe steel, slow strain rate method, sulfide, carbonate, inhibitor protection.

Received: October 25, 2013.

doi: $\underline{10.17675 / 2305-6894-2013-2-4-318-336}$

\section{Introduction}

The method involving straining of specimens at a constant deformation rate is widely used in studies on the liability of metals and alloys to stress corrosion cracking (SCC) [1]. The principle of Slow Strain Rate Test (SSRT) is that a smooth cylindrical specimen is slowly (usually $10^{-8}-10^{-4} \mathrm{~mm} / \mathrm{s}$ ) strained in a test environment until rupture occurs. The time to rupture is recorded, along with the metal plasticity parameters: relative elongation and relative reduction of area. The choice of the strain rate is of high importance in this method since the effect of the environment is only observed in some range of strain rates. At high strain rates, the corrosive medium has no time to modify the metal properties, so the metal strength and plasticity remain the same as in an inert medium. At too low strain rates, repassivation of the freshly formed metal surface can be faster than the processes that favor crack formation [2].

In comparison with other popular methods for SCC testing of metals (under static or cyclic strain or at constant specimen deformation), the SSRT method has the highest productivity, therefore it is used as an accelerated method for comparative assessment of the cracking resistance of various steels [2]. It is also noted that the SSRT method is quite sensitive to variations in electrode potential and composition of the corrosive environment [3]. 
In view of this, it appears that SSRT is a promising method for fast estimation of the effect of corrosive environment composition on the liability of pipe steel to cracking. It should also be taken into account that the higher the specimen strain rate is, the greater the mismatch between the test conditions and the metal strain conditions during pipeline operation becomes $[4,5]$. The lower the strain rate is, the better the metal degradation conditions represent the real ones, but the test duration may increase to an unacceptable extent. Hence, the primary goal of this study is to select the optimum specimen strain rate.

In those places where crevices are found on the outside pipe walls, the liquid under delaminated isolating coating (sub-film electrolyte) is a dilute aqueous solution of inorganic salts (mainly carbonates) and organic acids $[6,7,8]$. The sub-film electrolyte may contain dissolved hydrogen sulfide and bisulfide ions that are products of sulfatereducing bacteria life activity $[6,8]$.

The effect of a number of soil electrolyte components on the growth rate of corrosion cracks in X70 pipe steel in weakly-acidic $(\mathrm{pH} 5.5)$ citrate solution at static specimen straining has been studied [8]. It has been shown that the presence of sulfides and carbonates in a corrosive medium increases the crack growth rate, which is due to the stimulating effect of these additives on the anodic dissolution of steel in the potential region in the vicinity of the corrosion potential. It appears necessary to compare the data obtained previously with the results of pipe steel tests in the same corrosive media by SSRT method.

However, the citrate buffer solution used in [8] as the reference corrosive medium does not represent the composition of the sub-film electrolyte. Furthermore, the crack growth rate $\left(\sim 10^{-7} \mathrm{~mm} / \mathrm{s}\right)$ measured under specimen strain values within the kinetic curve plateau is about an order of magnitude higher than the crack growth rates most commonly observed on the outside walls of gas transmission pipelines [9]. The NS4 solution ( $\mathrm{pH} 6.5-$ 6.8) is generally used as the test medium to study the SCC of pipe steels. The ionic composition of this solution is based on analyses of liquids found under delaminated underground pipeline coatings [7]. The SSRT method makes it possible to study the effect of separate soil electrolyte components using NS4 as the reference solution.

Currently the majority of researchers agree that SCC of pipe steels in environments with near-neutral $\mathrm{pH}$ values results from a synergistic effect of local anodic dissolution of the metal and hydrogen absorption $[6,10]$. Hence, the use of corrosion inhibitors is a promising approach to pipeline protection from SCC. It is well known that corrosion inhibitors of various classes hinder the anodic dissolution of steel or cathodic processes (including cathodic hydrogen evolution and hydrogen absorption by a metal). Most often, they hinder both the anodic and cathodic partial electrode reactions.

In fact, Catamin $\mathrm{AB}$ (a quaternary ammonium compound) is among the most efficient inhibitors of hydrogen sulfide corrosion and hydrogen absorption by carbon and low-alloy steels [11]. Other well-known classes of corrosion inhibitors include arylcarboxylates, e.g., sodium nitrobenzoate, and heterocyclic $N$-containing compounds, in particular, 1,2,3benzotriazole. However, though it is principally possible to inhibit the SCC of pipe steels, this protection method has not been confirmed sufficiently. Data on the effect of corrosion 
inhibitors of various classes on the cracking resistance of X70 strength class pipe steels are quite scarce. Furthermore, in order to understand the mechanism of the protective effect of inhibitors on steel SCC, one needs to study at first their effect on the kinetics of partial corrosion reactions, whereas the electrochemical behavior of pipe steels in inhibited media simulating the soil (sub-film) electrolyte has almost not been studied.

In view of this, the purpose of this study included: first, to prove that the SSRT method is applicable for estimating the effect of soil components on the cracking resistance of pipe steel in media similar in composition to soil electrolytes; and second, to study whether the SCC of pipe steel can be hindered by organic corrosion inhibitors of various classes.

\section{Experimental}

Experiments were carried out using $1420 \times 18.7 \mathrm{~mm}$ specimens of X70 strength class pipe steel cut from a pipe. The chemical composition of the steel is provided elsewhere [8]. The steel has a yield point of $\sigma_{0.2}=538 \mathrm{MPa}$ and a tensile strength of $\sigma_{\mathrm{B}}=622 \mathrm{MPa}$. Cylindrical specimens (Fig. 1) with a working section diameter of $2.5 \mathrm{~mm}$ were manufactured in accordance with GOST (USSR State Standard) 1497-84.

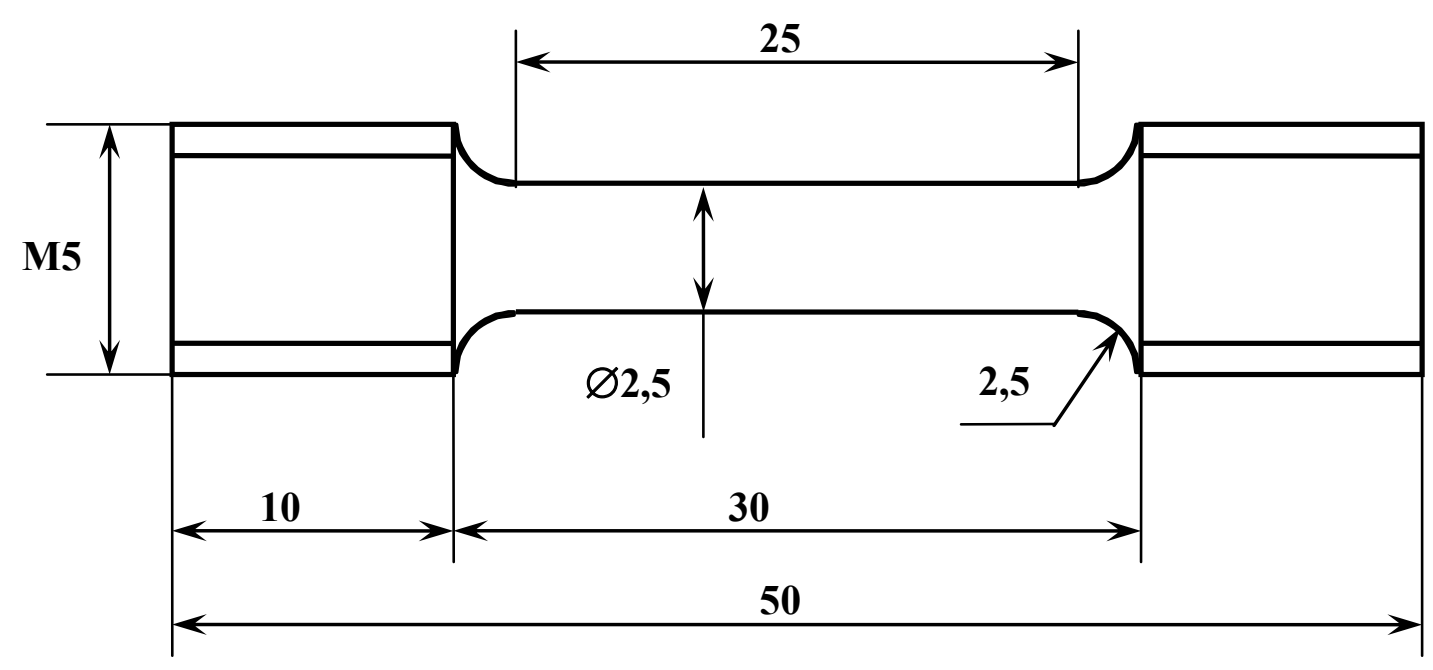

Fig. 1. Specimen for SSRT tests.

Mechanical treatment of specimens was carried out under conditions that excluded overheating and cold-work hardening in the working section. The working sections of the specimens were polished using grade "0" emery paper for finishing. A wire for potential measurements was soldered to one of the face surfaces. The specimen surface was degreased with acetone and, except for the working section, coated with a chemically resistant lacquer. 
The specimen length and the diameter of the working section before the experiment were measured to within $0.1 \mathrm{~mm}$. The diameter was measured at least in three places: in the middle of the working part and at its boundaries. The initial cross-section area of the specimen within its working part $\left(\mathrm{S}_{\mathbf{0}}\right)$ was calculated from the smallest diameter.

The specimens were fastened in electrically insulated grips of a HYBER AB tensile machine and immersed, together with the grips, in a test environment (Fig. 2).

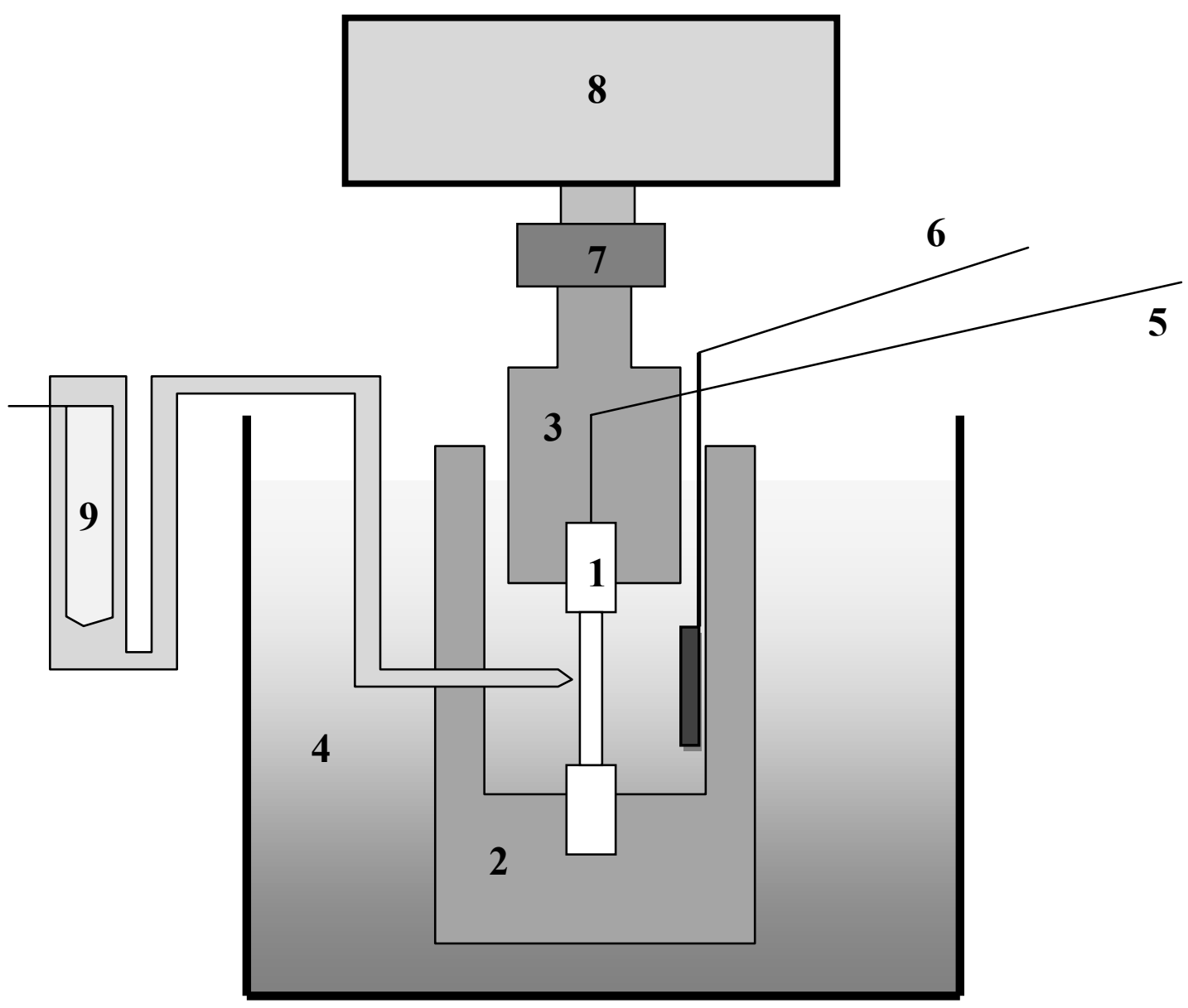

Fig. 2. Scheme of the test system: 1 , specimen; 2, immobile grip; 3, mobile grip; 4, vessel with test solution; 5 , contact for potential measurement; 6 , contact for the auxiliary electrode; 7 , dynamometer; 8 , electric motor with reduction gear; 9 , salt bridge.

The specimens were slowly strained at constant speed by means of a reducing gear. "Strain-time" data were recorded. The strain rate was varied from $2 \cdot 10^{-6}$ to $10^{-4} \mathrm{~mm} / \mathrm{s}$ (i.e., $6.6 \cdot 10^{-8}-3.3 \cdot 10^{-6} \mathrm{~s}^{-1}$ ).

An experiment at a speed of $2 \cdot 10^{-6} \mathrm{~mm} / \mathrm{s}$ lasted for about 10 days. In these cases, the test solution was intermittently (every $2-3$ days) replaced by a fresh portion. The experiments were carried out at room temperature with free access of air. 
The following electrolytes were used as reference test environments:

1. Citrate buffer solution $\left(0.08 \mathrm{M} \mathrm{C}_{6} \mathrm{H}_{8} \mathrm{O}_{7}+0.05 \mathrm{M} \mathrm{NaOH}+0.1 \mathrm{M} \mathrm{KCl}\right), \mathrm{pH} 5.5$.

2. Synthetic soil electrolyte NS4 [7] with the following composition: $\mathrm{KCl}(1.6 \mathrm{mM})+$ $\mathrm{NaHCO}_{3}(5.8 \mathrm{mM})+\mathrm{CaCl}_{2}(1.6 \mathrm{mM})+\mathrm{MgSO}_{4}(1.1 \mathrm{mM})+\mathrm{HCl}$ to $\mathrm{pH} 6.5$.

3. A mixture of NS4 solution with borate buffer solution $\left(0.1 \mathrm{M} \mathrm{H}_{3} \mathrm{BO}_{3}+0.008 \mathrm{M}\right.$ $\mathrm{Na}_{2} \mathrm{~B}_{4} \mathrm{O}_{7}$ ) with $\mathrm{pH} 6.5$.

The following additives were studied: soil electrolyte components that are potentially active toward steel $\mathrm{SCC}\left(\mathrm{Na}_{2} \mathrm{~S}, \mathrm{NaHCO}_{3}, \mathrm{NaNO}_{3}\right)$ as well as corrosion inhibitors (Catamin $\mathrm{AB}, 1,2,3$-benzotriazole, sodium benzoate and $m$-nitrobenzoate). The additives were added to the reference electrolyte as a portion of concentrated solution, either during electrolyte preparation or during a test.

After a test was completed and fracture of the specimen occurred, the relative reduction of area (RA) of the specimen working section was determined:

$$
R A=\frac{S_{0}-S_{f}}{S_{0}} \cdot 100 \%
$$

where: $S_{0}$ is the starting cross-section area of the specimen, $\mathrm{mm}^{2} ; S_{f}$ is the cross-section area of the specimen after the fracture, $\mathrm{mm}^{2}$.

To determine the relative reduction of specimen area after the fracture, a digital scanner was used to make a picture of the fractured surface. Based on the picture, the cross-section area of the specimen at the place of fracture $(S)$ was computed using standard graphical programs.

A typical dependence of strain $(F)$ on test time $(t)$ and hence on specimen elongation during slow specimen straining at a constant rate is shown in Fig. 3.

Segment 1 of the "strain-time" plot corresponds to the region of elastic reversible metal deformation. In segment 2, irreversible plastic deformation of the specimen is developed. In segment 3, fracture of the specimen occurs. In region 2, conditions for crack initiation and intense development are created in a strained metal. Competition between plastic deformation processes and metal cracking is responsible for the variable neck shape in the place of specimen fracture. In fact, if steel cracking resistance is high, plastic deformation of the metal results in considerable elongation of the specimen and formation of a thin neck with a small cross-section area. A decline in metal plasticity and development of corrosion cracks results in brittle fracture that occurs without considerable specimen elongation and with a large cross-section area at the place of fracture.

If the slow specimen strain is started not from zero strain but from a value in the vicinity of the yield point (point A, Fig. 3), the RA nearly does not change, but the time until specimen fracture can be shortened. In view of this, the majority of experiments in various corrosive environments were carried out starting from $F \approx 0.95 \sigma_{\mathrm{T}}$. 


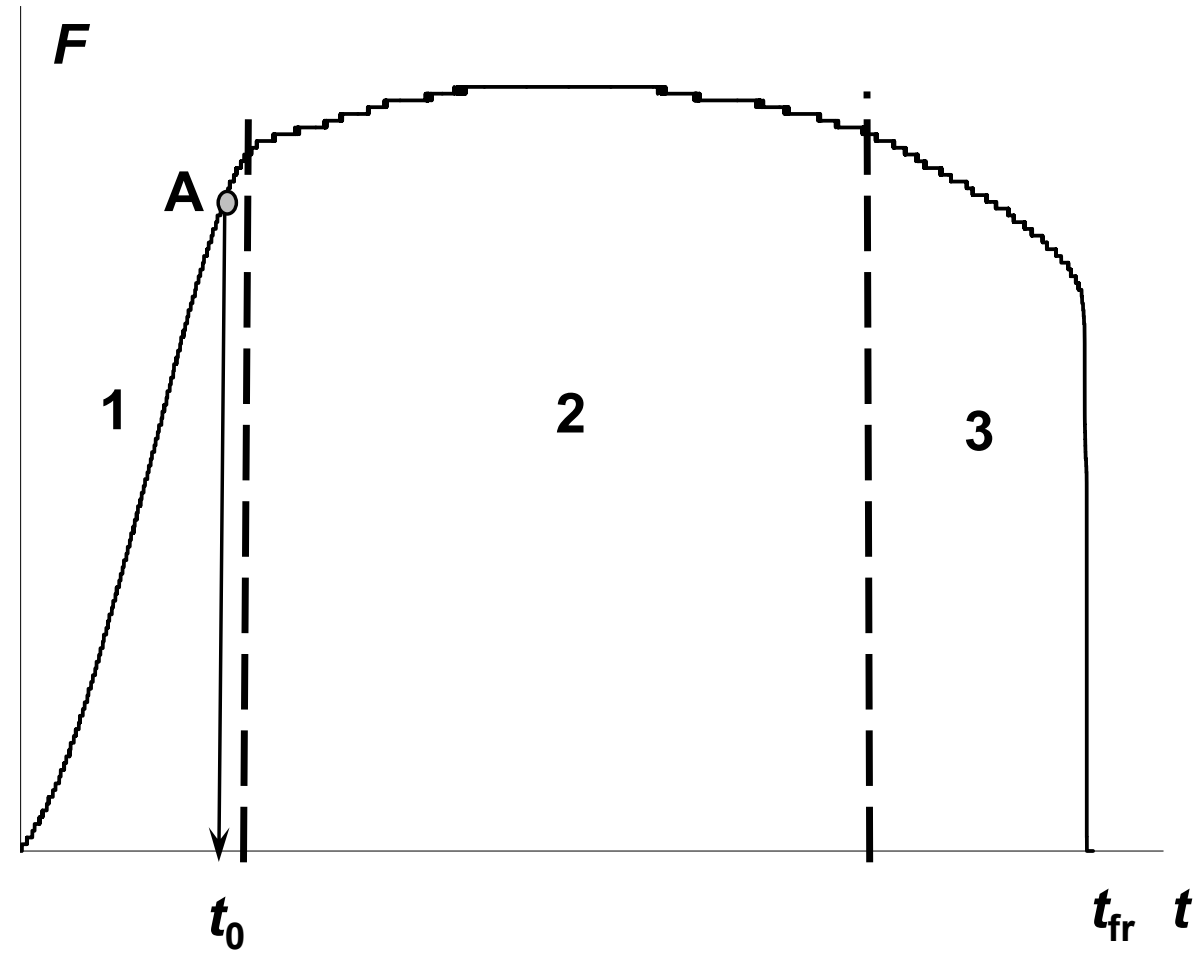

Fig. 3. Scheme of mechanical strain variation during an experiment in case of slow specimen straining. Please see the text for explanations.

Since the composition of the corrosive medium does not affect the metal plastic properties at sufficiently high strain rates, we determined the maximum acceptable specimen strain rate. Comparison of test results in the air and in NS4 solution with addition of sulfide and carbonate and at various strain rates shows that the effect of the medium on the relative reduction of specimen area is fairly well observable at $2 \cdot 10^{-6} \mathrm{~mm} / \mathrm{s}$ strain rate, but this effect ceases at higher rates (Fig. 4). Hence, $2 \cdot 10^{-6} \mathrm{~mm} / \mathrm{s}$ is the maximum acceptable rate in studies of the effect of soil electrolyte composition, so the subsequent tests were carried out using this specimen strain rate.

Polarization curves were recorded in a standard three-electrode cell at room temperature with free access of air. Specimens of X70 pipe steel with an area of $0.3 \mathrm{~cm}^{2}$ served as working electrodes. The potentials are reported against SHE.

\section{Results and discussion}

Effect of soil electrolyte components on the cracking resistance of X70 steel at the free corrosion potential in citrate buffer with $p H$ 5.5. Comparison of SSRT and static strain of specimens with a preformed crack.

Figure 5a shows the diagrams of specimen straining in air (curve 1) in reference citrate buffer with $\mathrm{pH} 5.5(\mathrm{CB})$ (curve 2) and in the same buffer additionally containing $10 \mathrm{mM} \mathrm{Na}_{2} \mathrm{~S}$ (curve 3), $10 \mathrm{mM} \mathrm{Na} \mathrm{HCO}_{3}$ (curve 4), or $0.1 \mathrm{M} \mathrm{NaNO}_{3}$ (curve 5). In all cases, the presence of a corrosive environment facilitates specimen fracture in comparison with the test in air: the time to specimen fracture and the maximum bearable strain 
(fracture strain) decrease. The time to fracture in pure citrate buffer is considerably smaller than that in air. The minimum time to fracture is observed in solutions containing sulfide and hydrocarbonate (curves 3 and 4).

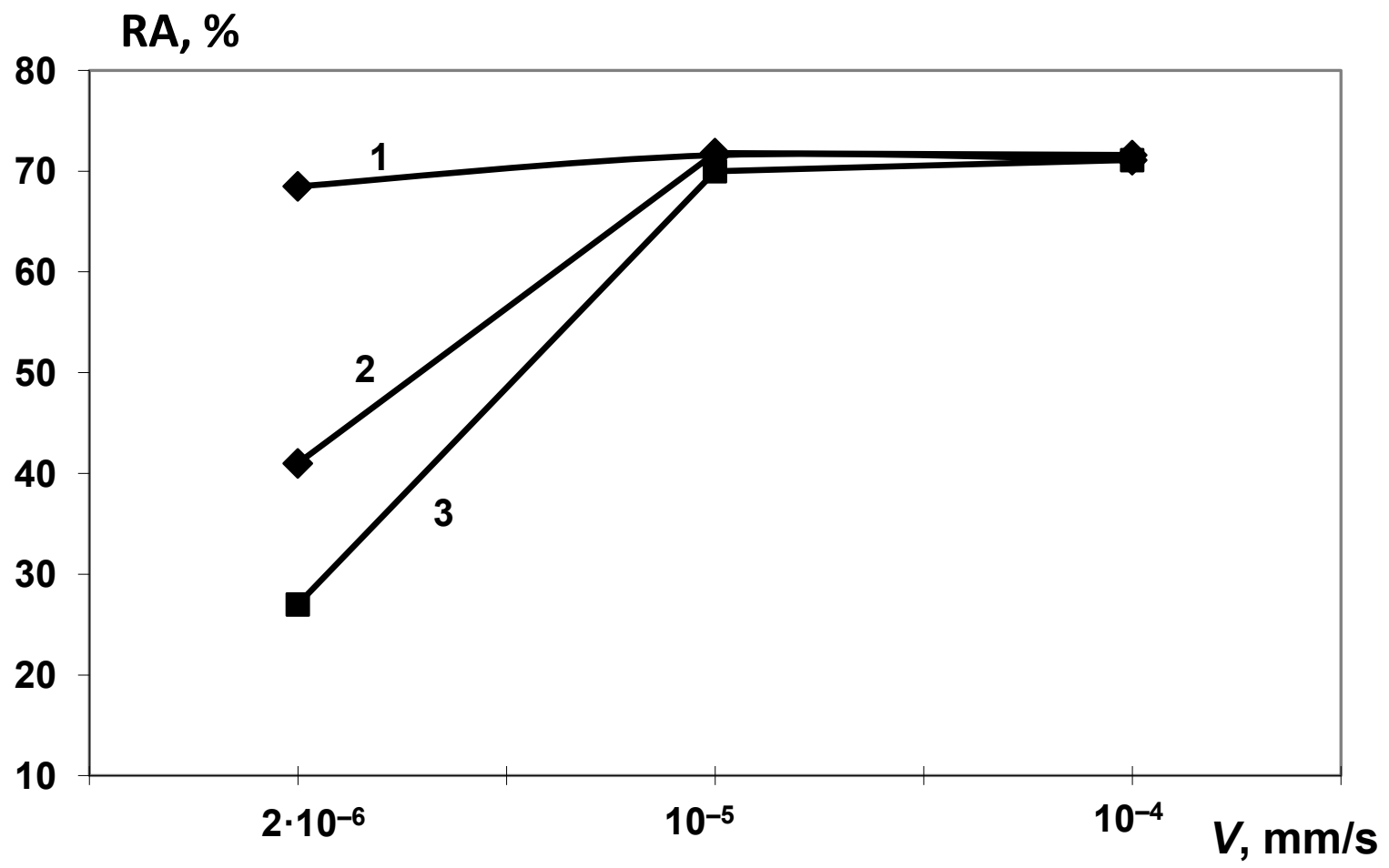

Fig. 4. Plot of RA value versus specimen strain rate in air (1) and in solutions: NS4 $+5 \cdot 10^{-3} \mathrm{M}$ $\mathrm{Na}_{2} \mathrm{HCO}_{3}(2), \mathrm{NS} 4+10^{-3} \mathrm{M} \mathrm{Na} 2 \mathrm{~S}(3)$.

The RA values obtained for steel in these media are shown in Fig. 5b. Addition of $10 \mathrm{mM} \mathrm{Na}_{2} \mathrm{~S}$ to $\mathrm{CB}$ results in a decrease in the relative reduction of specimen area, which indicates that the liability of the steel to corrosion cracking increases. Addition of $10 \mathrm{mM}$ $\mathrm{Na}_{2} \mathrm{HCO}_{3}$ also impairs steel cracking resistance, though the RA value is higher than that in the presence of $\mathrm{Na}_{2} \mathrm{~S}$. The effect of nitrate ions on the time to specimen fracture and RA value is rather small (Fig. 5, curve 5). Comparison of Figs. 5a and 5b shows that the fracture parameters being determined, i.e., time to fracture and relative reduction of area, change in a symbate way in various solutions. Therefore, only the RA values are shown in subsequent Figures.

As shown in [8], addition of $\mathrm{Na}_{2} \mathrm{~S}$ or $\mathrm{Na}_{2} \mathrm{HCO}_{3}$ accelerates the growth of corrosion cracks in pipe steel under static load in citrate buffer with $\mathrm{pH}$ 5.5. The accelerating effect of sulfide is stronger than that of carbonate (Table 1). Nitrate ions have no accelerating effect on the crack growth rate in static tests and almost do not change the kinetics of steel anodic dissolution in this medium. 

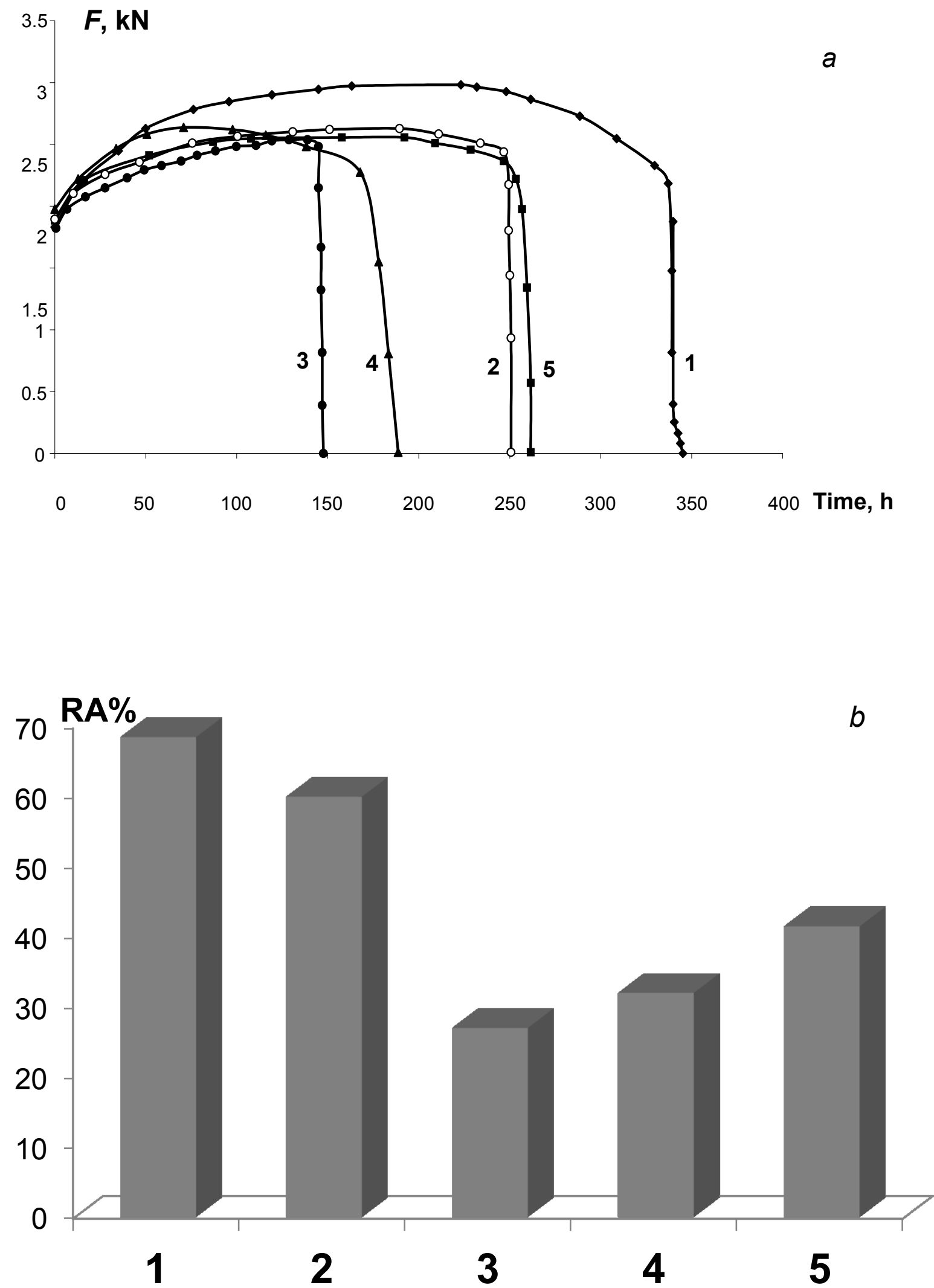

Fig. 5. Plot of mechanical strain versus strain time $(a)$ and relative reduction in specimen area (b) in air (1) and in solutions: $\mathrm{CB}(2), \mathrm{CB}+10 \mathrm{mM} \mathrm{Na}_{2} \mathrm{~S}(3), \mathrm{CB}+10 \mathrm{mM} \mathrm{Na}_{2} \mathrm{HCO}_{3}$ (4), $\mathrm{CB}+0.1 \mathrm{M} \mathrm{NaNO}_{3}$ (5). 
Thus, comparison of crack growth rates under static strain of pipe steel and the characteristics of its cracking resistance obtained by SSRT shows that both methods give qualitatively similar results on the effect of soil electrolyte components on the liability of steel to SCC.

It should be noted that at $V<10^{-7} \mathrm{~mm} / \mathrm{s}$, the existing methods of recording the crack length growth (e.g., by measurement of the specimen electric resistance) require prolonged tests (tens of days) [5,8]. This fact complicates the studies in solutions with small corrosivity. The SSRT method makes it possible to study the cracking resistance of steels in media similar in composition to soil electrolytes, e.g., in NS4 solution.

Table 1. Corrosion crack growth rate $(V)$ in X70 pipe steel in citrate buffer $(\mathrm{pH} 5.5)$ with various additives at the stress intensity factor values corresponding to the plateau region of the kinetic curve of material fracture [8].

\begin{tabular}{cc}
\hline Medium & $\boldsymbol{V}, \mathbf{m m} / \mathbf{s}$ \\
\hline $\mathrm{CB}$ & $1.3 \cdot 10^{-7}$ \\
$\mathrm{CB}+10 \mathrm{mM} \mathrm{Na}_{2} \mathrm{HCO}_{3}$ & $1.7 \cdot 10^{-7}$ \\
$\mathrm{CB}+10 \mathrm{mM} \mathrm{Na}_{2} \mathrm{~S}$ & $1.9 \cdot 10^{-7}$ \\
$\mathrm{CB}+100 \mathrm{mM} \mathrm{NaNO}_{3}$ & $1.2 \cdot 10^{-7}$ \\
\hline
\end{tabular}

Effect of soil electrolyte components on the cracking resistance of X70 steel at the free corrosion potential in NS4 solution with $\mathrm{pH} 6.5$

Figure 6 shows the results of steel tests by the SSRT method in synthetic soil electrolyte NS4 with pH 6.5. The RA value amounts to $60 \%$ in NS4 solution. It decreases to $27 \%$ and $32 \%$ upon addition of 1 and $10 \mathrm{mM} \mathrm{Na}_{2} \mathrm{~S}$, respectively. Hence, sulfide accelerates steel SCC and its effect is stronger at the lower concentration $(1 \mathrm{mM})$. The presence of $5 \mathrm{mM} \mathrm{Na}_{2} \mathrm{HCO}_{3}$ also decreases the cracking resistance of steel ( $\left.\mathrm{RA}=41 \%\right)$. In general, the effect of sulfide and carbonate on the cracking resistance of pipe steel in soil electrolyte with pH 6.5 is the same as that in the more acidic citrate buffer solution.

Effect of organic inhibitors on anodic dissolution of steel X70 in buffered synthetic soli electrolyte NS4

In order to stabilize the solution $\mathrm{pH}$ near the electrode under polarization, experiments were carried out in a mixture of soil electrolyte NS4 and borate buffer with pH 6.5 (BB). It is known that borate ions do not affect the kinetics of iron dissolution [12]. As follows from the anodic curves obtained (Fig. 7), dissolution of pipe steel in buffered NS4 solution occurs at high rates (curve 1 ) and the current density required for its passivation even in the absence of $\mathrm{H}_{2} \mathrm{~S}$ is $i_{p} \approx 1300 \mu \mathrm{A} / \mathrm{cm}^{2}$. Under these conditions, addition of $1 \mathrm{~g} / \mathrm{l} \mathrm{Catamin} \mathrm{AB}$ facilitates passivation, decreasing the passivation current nearly fourfold, and increases the free corrosion potential $\left(\mathrm{E}_{\mathrm{cor}}\right)$ by more than $0.1 \mathrm{~V}$ (curve $1^{\prime}$ ). However, it does not provide spontaneous steel passivation. Furthermore, the inhibitor does not enhance the passive state stability, since the pitting potential $\left(E_{\mathrm{pt}}\right)$ nearly does not change $\left(E_{\mathrm{pt}} \approx 0.1 \mathrm{~V}\right)$. 


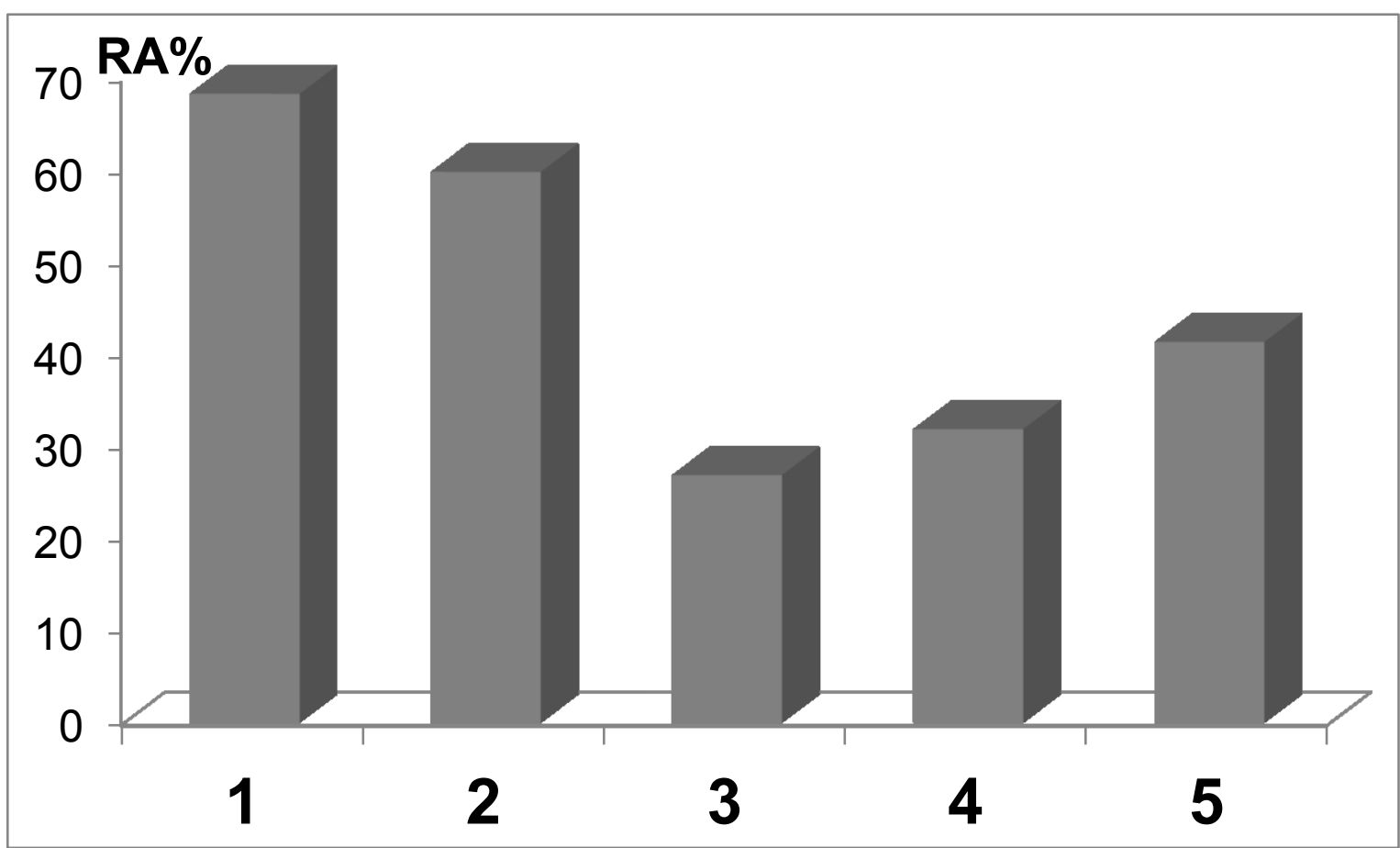

Fig. 6. Relative reduction of specimen area in air (1) and in solutions: NS4 (2), NS4 + $1 \mathrm{mM}$ $\mathrm{Na}_{2} \mathrm{~S}(3), \mathrm{NS} 4+10 \mathrm{mM} \mathrm{Na} 2 \mathrm{~S}(4), \mathrm{NS} 4+5 \cdot 10^{-3} \mathrm{M} \mathrm{NaHCO}_{3}$ (5).

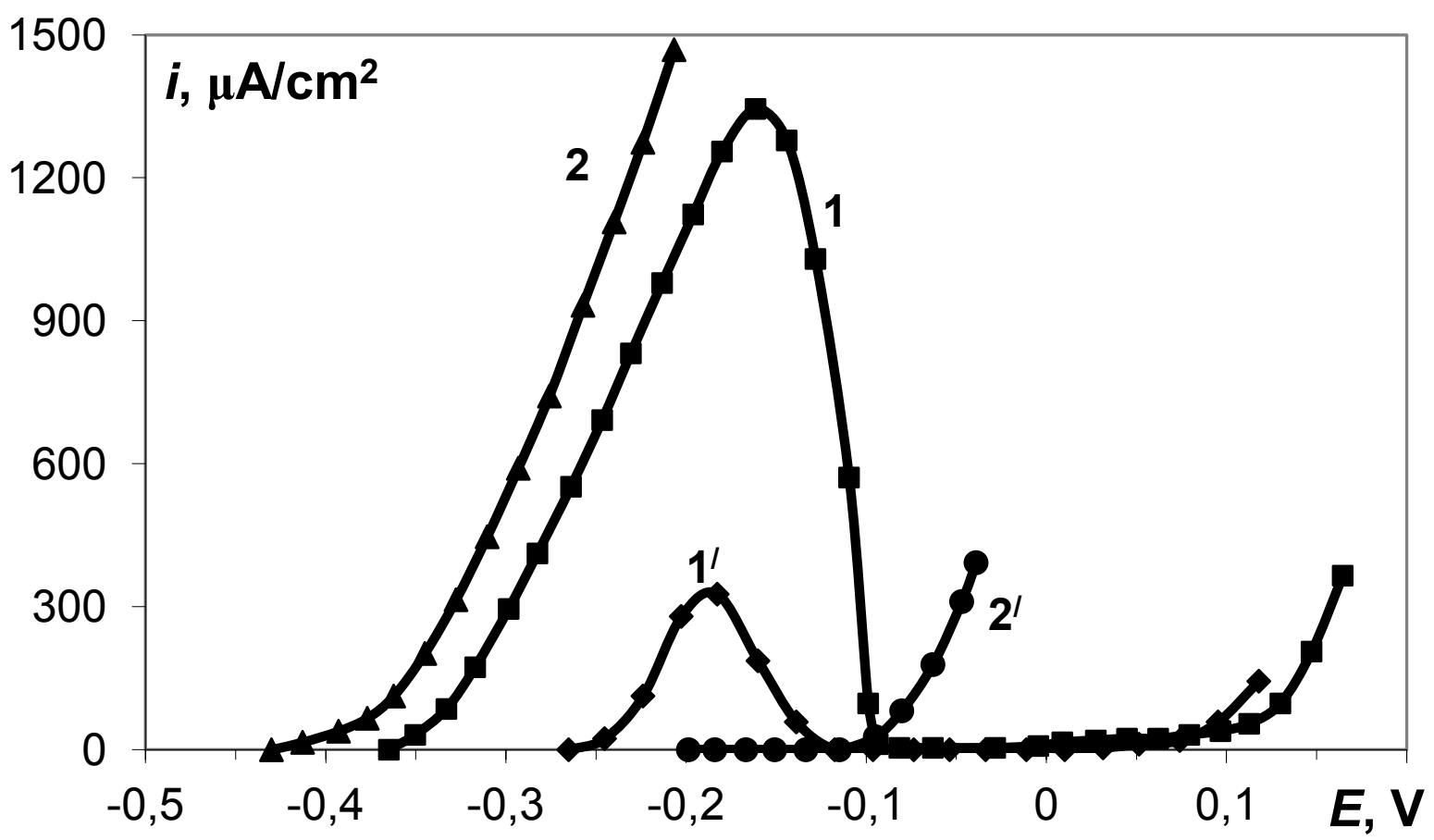

Fig. 7. Anodic curves on X70 pipe steel in NS4 + BB solution without $\left(1,1^{\prime}\right)$ and with $10 \mathrm{mmol} / \mathrm{L} \mathrm{Na} \mathrm{S}_{2} \mathrm{~S}\left(2,2^{\prime}\right)$, in the presence of Catamin AB, g/L: $0(1,2)$ and $1\left(1^{\prime}, 2^{\prime}\right)$.

It is known that hydrogen sulfide present in a corrosive medium plays a dual role in the corrosion and electrochemical behavior of steels. On the one hand, it accelerates the 
active dissolution of steel and causes localization of corrosion damage. It also stimulates hydrogen absorption by steel. On the other hand, by creating surface sulfide layers with thickness varying in a wide range (from nanometers to millimeters) depending on the conditions, hydrogen sulfide can also facilitate adsorption of corrosion and hydrogen absorption inhibitors. This is usually the case if cation-active compounds, such as various amines or quaternary ammonium compounds, are used as inhibitors.

In fact, addition of $10 \mathrm{mmol} / \mathrm{L} \mathrm{H}_{2} \mathrm{~S}$ to NS4 solution considerably accelerates the dissolution of pipe steel and prevents its passivation (Fig. 7, curve 2). Addition of the same concentration of Catamin $\mathrm{AB}(1 \mathrm{~g} / \mathrm{L})$ nearly suppresses active dissolution (curve $\left.2^{\prime}\right)$. The free corrosion potential increases to $E_{\text {cor }}=-0.33 \mathrm{~V}$ but does not reach values typical of steel passive state in neutral solutions of anodic inhibitors. This fact is due to the ability of Catamin AB to slow down not only the anodic but also cathodic reaction on steels in $\mathrm{H}_{2} \mathrm{~S}$ containing media [11].

Sodium benzoate is among the most thoroughly studied anion-active inhibitors. Furthermore, it is industrially available and nearly non-toxic. Sodium benzoate is the parent of an extensive and well-studied reaction series of arylcarboxylates. Addition of sodium benzoate decreases somewhat the passivation current on pipe steel in NS4 + BB solution containing no $\mathrm{H}_{2} \mathrm{~S}$ (Fig. 8). Sodium benzoate can prevent the local depassivation of X70 steel, not only by increasing $\mathrm{E}_{\text {pit }}$ but also, apparently, by hindering pit growth. The inhibitive effect of sodium benzoate in the passive range of potentials increases with an increase in its concentration in solution. This is quite predictable, considering the anionic character of the additive.

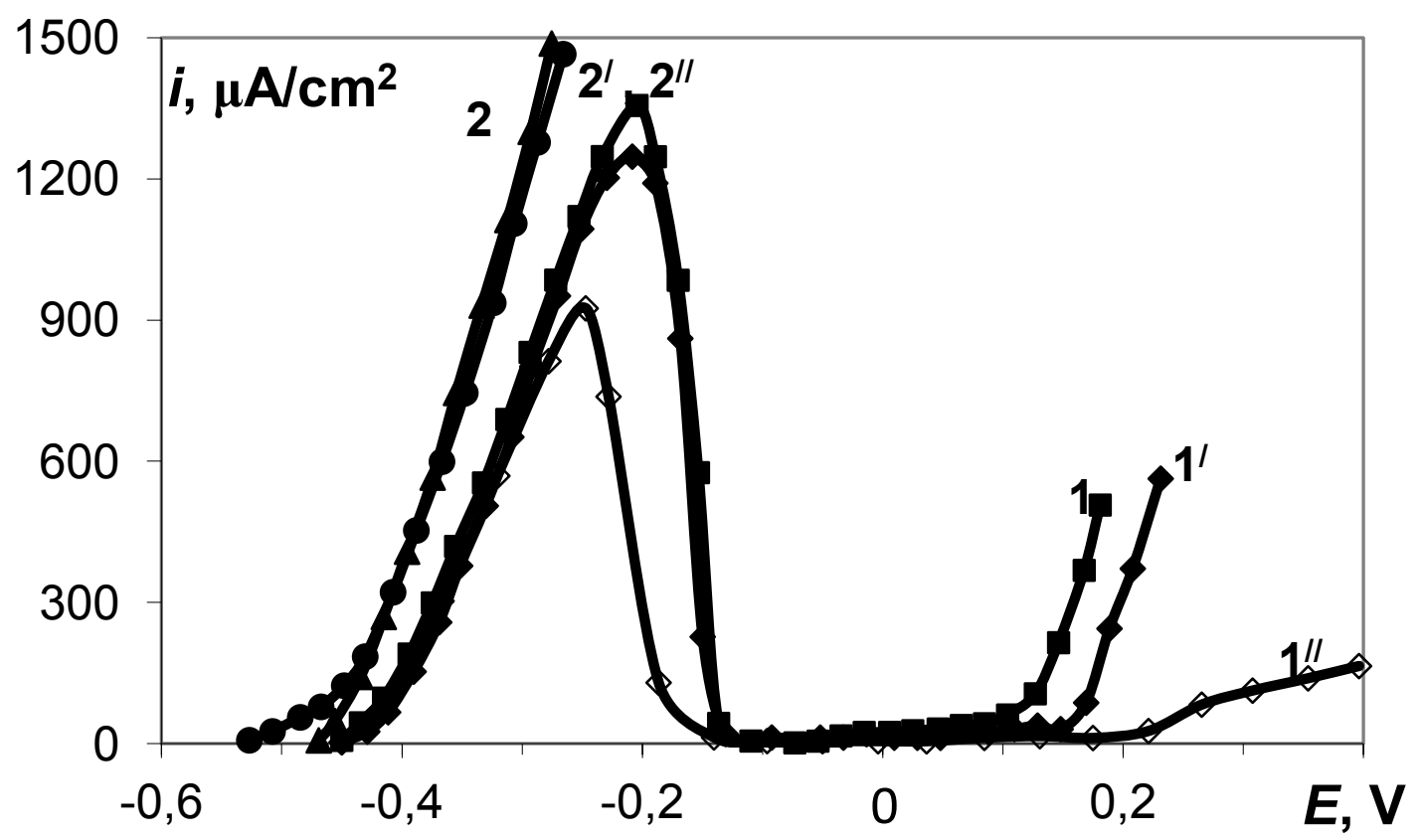

Fig. 8. Anodic curves on X70 pipe steel in NS4 + BB solution without $\left(1,1^{\prime}, 1^{\prime \prime}\right)$ and with $10 \mathrm{mmol} / \mathrm{L} \mathrm{H}_{2} \mathrm{~S}\left(2,2^{\prime}, 2^{\prime \prime}\right)$, in the presence of sodium benzoate, $\mathrm{g} / \mathrm{L}: 0(1,2), 0.5\left(1^{\prime}, 2^{\prime}\right)$ and 1.5 (1" $\left.2^{\prime \prime}\right)$. 
Unfortunately, the protective effect of this inhibitor in the presence of $\mathrm{H}_{2} \mathrm{~S}$ is hard to identify on anodic polarization curves without additional studies. However, some increase in $\mathrm{E}_{\mathrm{cor}}$ allows us to believe that, though sodium benzoate does not have a passivating effect in this environment, it can slow down the corrosion of steel in active state to some extent. This gives a reason to hope that it would inhibit SCC, though not too efficiently.

Of anion-active inhibitors, sodium $m$-nitrobenzoates has both high efficiency and oxidizing properties. In fact, as one can see in the polarization curves (Fig. 9), addition of $1 \mathrm{~g} / \mathrm{L}$ sodium nitrobenzoate to the solution in the absence of $\mathrm{H}_{2} \mathrm{~S}$ facilitates X70 steel passivation by decreasing $i_{p}$ almost fivefold (curves 1 and $1^{\prime}$ ), i.e., it is at least not inferior to Catamin $\mathrm{AB}$ in this respect. However, the mechanisms of action of these two corrosion inhibitors differ considerably. Catamin $\mathrm{AB}$ hinders both electrode reactions on the metal due to adsorption, whereas, being a strong oxidizing agent, the nitrobenzoate anion accelerates the cathodic reaction owing to reduction on the electrode. In this case, the rate of steel dissolution at active dissolution potentials decreases not due to adsorption but because of an increase in the $\mathrm{pH}$ of the near-electrode solution layer [13]. In turn, inhibitor adsorption itself occurs at more positive potentials, which makes it possible to increase the pitting potential considerably and prevent pit formation in a wide range of anodic potentials. This is particularly evident at a high concentration of sodium $m$-nitrobenzoate, $C_{\text {in }}=3.0 \mathrm{~g} / \mathrm{L}$ (curve $1^{\prime \prime}$ ).

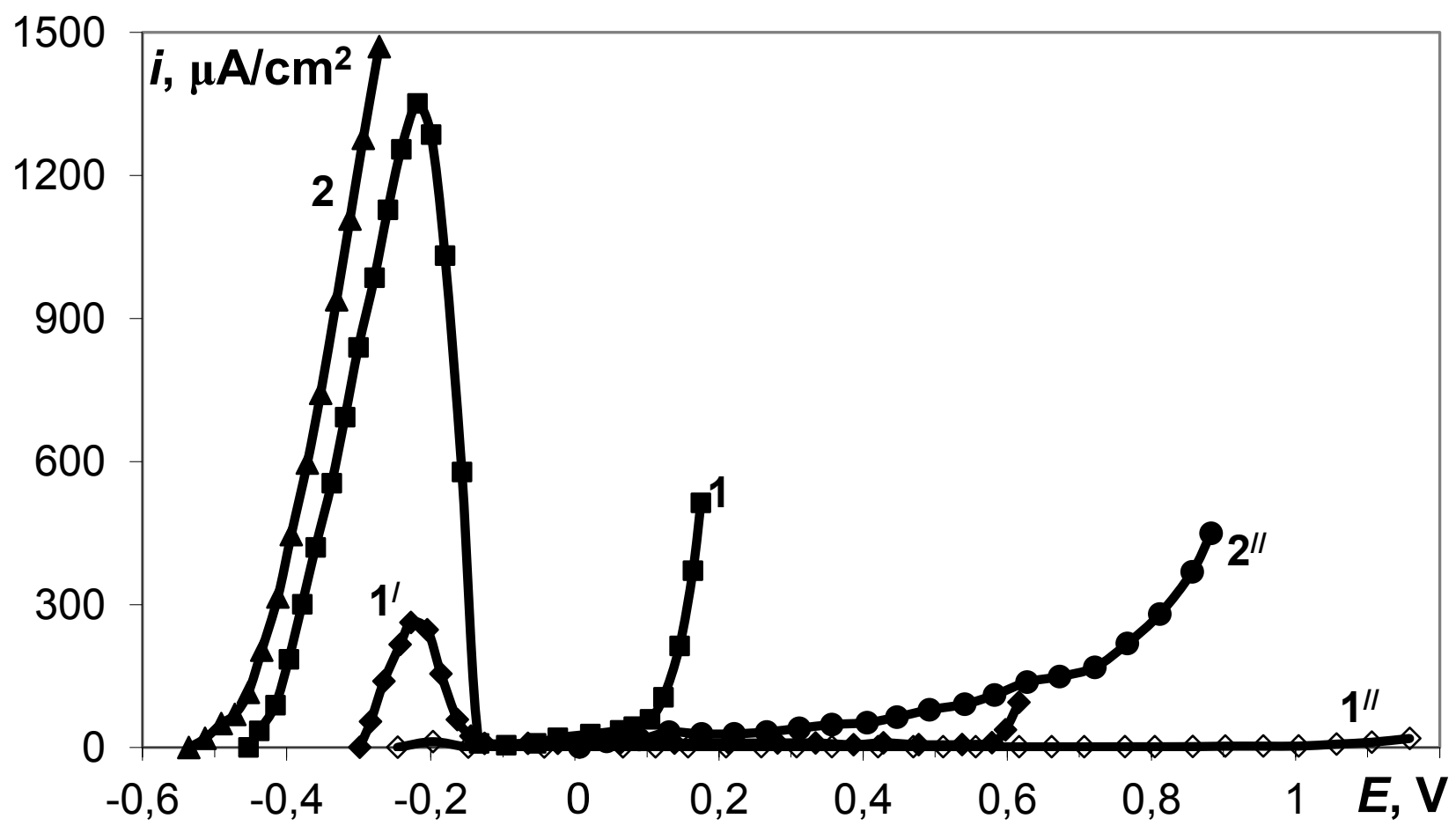

Fig. 9. Anodic curves on X70 pipe steel in NS4 + BB solution without $\left(1,1^{\prime}, 1^{\prime \prime}\right)$ and with 10 $\mathrm{mmol} / \mathrm{L} \mathrm{H}_{2} \mathrm{~S}\left(2,2^{\prime}, 2^{\prime \prime}\right)$, in the presence of sodium $m$-nitrobenzoate, $\mathrm{g} / \mathrm{L}: 0(1,2), 1.0\left(1^{\prime}\right)$ and $3.0\left(1^{\prime \prime}, 2^{\prime \prime}\right)$. 
In the presence of $\mathrm{H}_{2} \mathrm{~S}$, sodium $m$-nitrobenzoate can even passivate pipe steel at $C_{\text {in }}=3.0 \mathrm{~g} / \mathrm{L}$ by shifting the corrosion potential towards passive potentials. Studies of the mechanism of concurrent action of hydrogen sulfide and sodium $m$-nitrobenzoate is beyond the scope of this paper. However, it can be assumed that an increase in solution $\mathrm{pH}$ in the near-electrode layer modifies the kinetics of formation and the composition of iron sulfide films. It may also not be ruled out that the secondary products of sodium $\mathrm{m}$ nitrobenzoate reduction stabilize the sulfide layers or passivating oxide layers.

1,2,3-Benzotriazole (BTA), which is a weak NH-acid, is a known corrosion inhibitor of copper and its alloys and has lately been applied to protect other metals as well. As shown recently $[14,15]$, its specific feature in protection of iron and low-carbon steel in neutral borate buffer is that it has a good passivating ability due to strong adsorption on oxide-free surfaces and low adsorptivity on oxidized surfaces.

Analysis of anodic polarization curves of steel X70, in the absence of $\mathrm{H}_{2} \mathrm{~S}$ in buffer solution containing as little as $0.5 \mathrm{~g} / \mathrm{L}$ BTA, shows that $i_{p}$ decreases 36 -fold (Fig. 10, curves 1 and $1^{\prime}$ ). This indicates that the inhibitor manifests high protective properties at potentials of pipe steel active dissolution. It this case, the free corrosion potential increases by more than $0.10 \mathrm{~V}$ and remains in the potential region of steel active dissolution. On the other hand, this inhibitor does not at all hinder the local depassivation of steel since it does not increase the pit initiation potential in the solution in question.

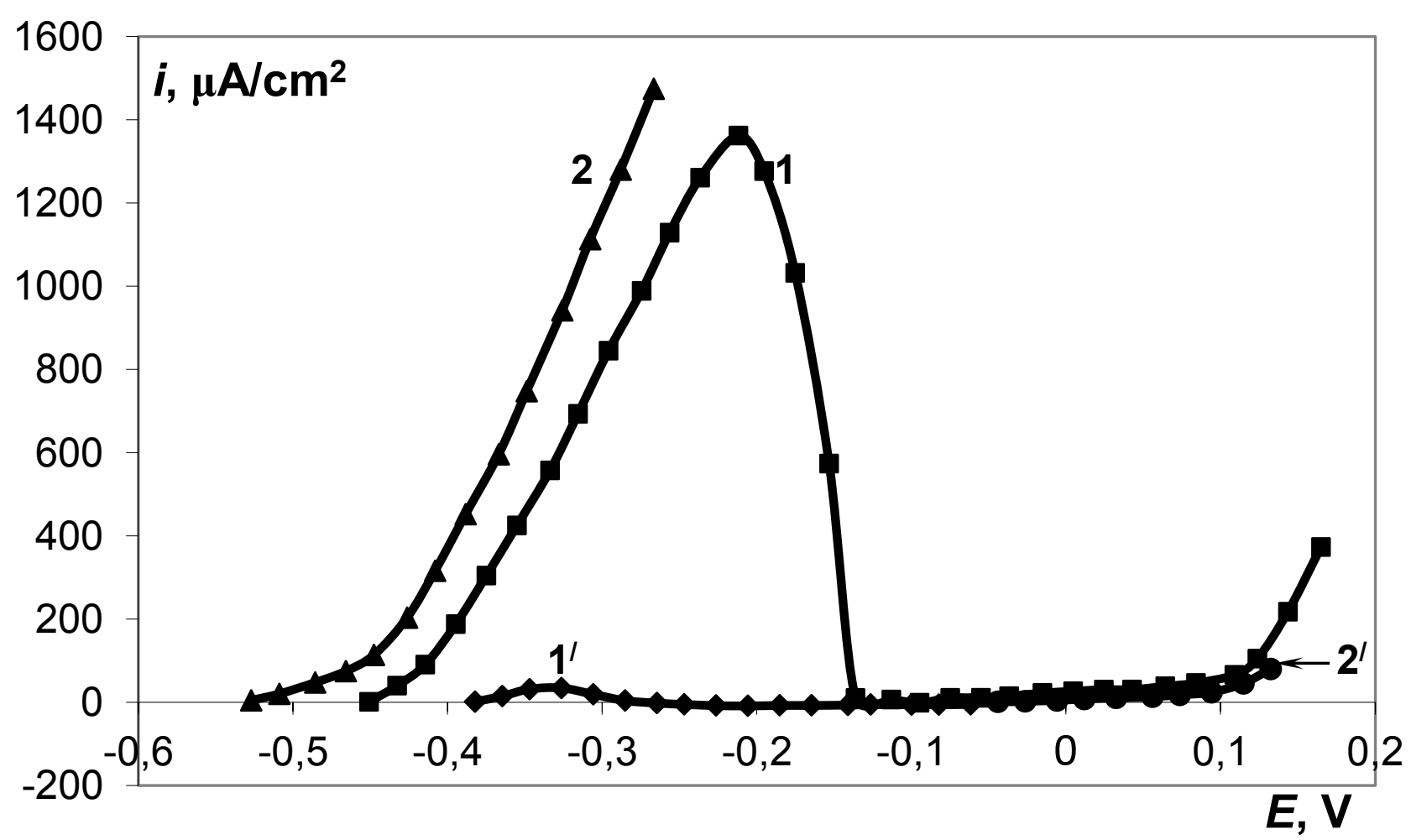

Fig. 10. Anodic curves on X70 pipe steel in NS4 + BB solution without $\left(1,1^{\prime}\right)$ and with $10 \mathrm{mmol} / \mathrm{L} \mathrm{Na}_{2} \mathrm{~S}\left(2,2^{\prime}\right)$, in the presence of BTA, $\mathrm{g} / \mathrm{L}: 0(1,2)$ and $0.5\left(1^{\prime}, 2^{\prime}\right)$. 
However, passivation of pipe steel is facilitated and the free corrosion potential is shifted to the passive region in the presence of $\mathrm{H}_{2} \mathrm{~S}$. Considering the inability of BTA to hinder local depassivation, this can have a harmful effect on steel cracking, hence BTA can primarily be considered as an inhibitor of steel SCC in the absence of hydrogen sulfide in the corrosive medium.

Thus, addition of inhibitors to a solution similar in composition to the corrosive medium causing SCC of underground pipelines results in considerable hindrance of anodic dissolution of pipe steel. Taking into account that steel dissolution is the main reason of crack growth in pipe steels in weakly acidic media [7], it is of interest to consider whether anodic corrosion inhibitors can be used to hinder metal SCC.

Effect of corrosion inhibitors on the cracking resistance of X70 steel at the free corrosion potential

Addition of Catamin $\mathrm{AB}$ both to $\mathrm{CB}$ ( $\mathrm{pH}$ 5.5) (Fig. 11) and to NS4 solution (pH 6.5) (Fig. 12) increases the RA value, i.e., decreases the liability of steel to SCC. The protective effect of Catamin $\mathrm{AB}$ is stronger in sulfide-containing media than in reference solutions. In fact, addition of Catamin $\mathrm{AB}$ to pure citrate buffer increases RA from 26 to $42 \%$, while RA increases to $49 \%$ in the presence of $\mathrm{Na}_{2} \mathrm{~S}$ (Fig. 11). The other parameter of steel cracking resistance, i.e., the time to specimen fracture, also increases in the presence of Catamin $\mathrm{AB}$. The time to fracture is $251 \mathrm{~h}$ in pure citrate buffer, $288 \mathrm{~h}$ in the presence of $1 \mathrm{~g} / \mathrm{L}$ Catamin $\mathrm{AB}$, and $308 \mathrm{~h}$ in the inhibited sulfide-containing solution.

Figure 12 presents the plot of RA vs. Catamin $\mathrm{AB}$ concentration (in the range of $0.1-$ $1.5 \mathrm{~g} / \mathrm{L}$ ) in NS4 solution containing $1 \mathrm{mM} \mathrm{Na}_{2} \mathrm{~S}$. Addition of Catamin $\mathrm{AB}$ to this solution increases both the RA value (from 28 to $59 \%$ ) and the time to specimen fracture (Table 2), i.e., steel SCC is inhibited.

Table 2. Time to specimen fracture $\left(t_{\mathrm{fr}}\right)$ in SSRT tests of X70 pipe steel in NS4 solution containing $1 \mathrm{mM}$ $\mathrm{Na}_{2} \mathrm{~S}$ and an inhibitor.

\begin{tabular}{cc}
\hline Catamin AB concentration, $\mathbf{g} / \mathbf{L}$ & $\boldsymbol{t}_{\mathbf{f r}}, \mathbf{h}$ \\
\hline 0 & 213 \\
0.1 & 236 \\
0.25 & 274 \\
0.5 & 324 \\
1.0 & 330 \\
1.5 & 260 \\
\hline
\end{tabular}

The maximum protective effect of the inhibitor, as determined both from the time to specimen fracture and from the RA value, is observed at $1.0 \mathrm{~g} / \mathrm{L}$ of Catamin $\mathrm{AB}$. It will be shown below that Catamin $\mathrm{AB}$ has an even higher protective effect if steel potential is slightly shifted in the negative direction. 


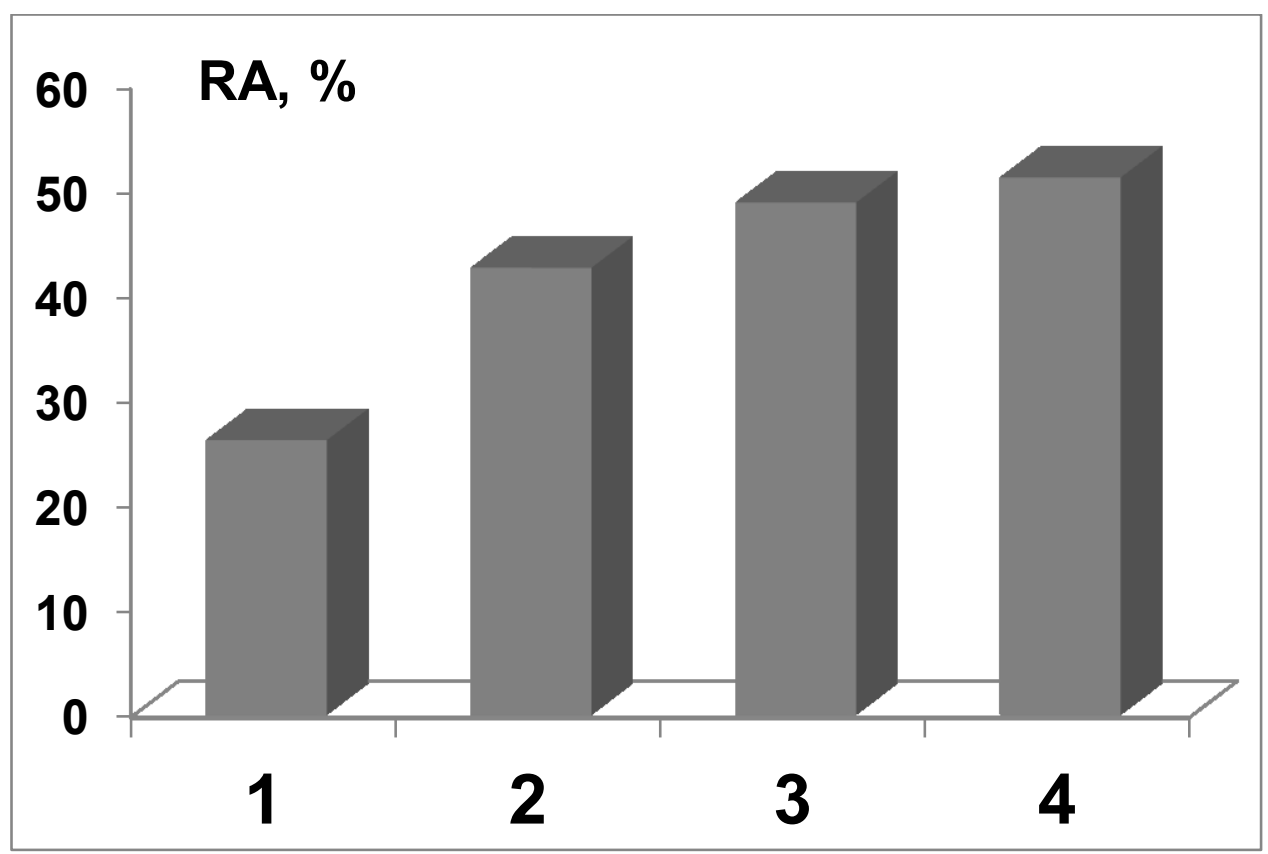

Fig. 11. Relative reduction of specimen area in solutions: $\mathrm{CB}(1), \mathrm{CB}+1 \mathrm{~g} / \mathrm{L}$ Catamin $\mathrm{AB}(2)$; $\mathrm{CB}+1 \mathrm{~g} / \mathrm{L}$ Catamin $\mathrm{AB}+10 \mathrm{mM} \mathrm{Na}_{2} \mathrm{~S}$ (3); CB + 0.1 M BTA (4).

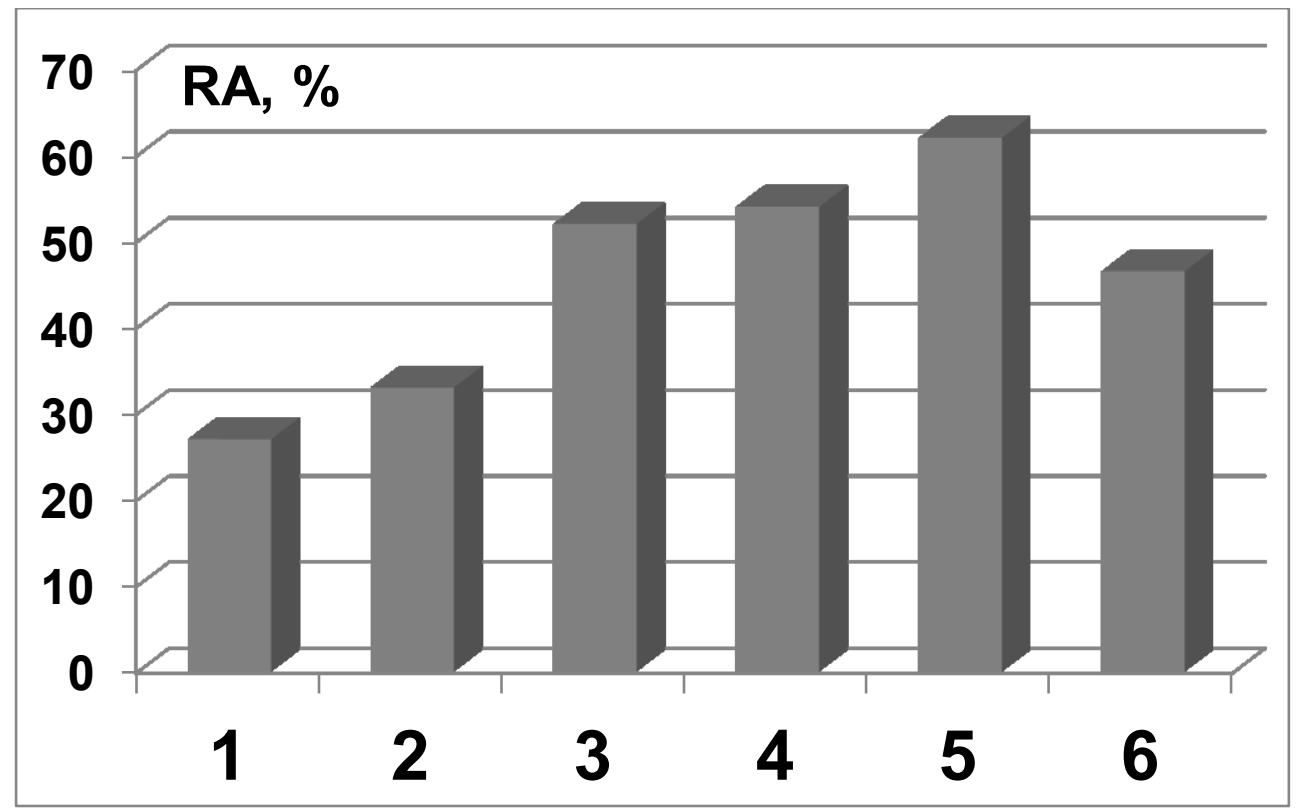

Fig. 12. Relative reduction of specimen area in NS4 $+1 \mathrm{mM} \mathrm{Na}_{2} \mathrm{~S}$ solution also containing Catamin AB, g/L: 0 (1), 0.1 (2); 0.25 (3), 0.5 (4), 1.0 (5), and 1.5 (6).

Addition of $10 \mathrm{mM}$ BTA to $\mathrm{CB}$ increases the RA value considerably (from 26 to $51.3 \%$ ) (Fig. 11). It this case, the time to specimen fracture amounts to $336 \mathrm{~h}$, which is nearly the same as the time to pipe steel fracture in air $(346 \mathrm{~h})$.

The results of benzoate and $m$-nitrobenzoate tests as pipe steel SCC inhibitors are shown in Fig. 13. The tests were carried out in NS4 + BB solution with addition of $10 \mathrm{mM}$ $\mathrm{Na}_{2} \mathrm{~S}$. It is evident that the presence of sodium benzoate or $m$-nitrobenzoate in the sulfide- 
containing medium results in some inhibition of cracking, though the efficiency of these inhibitors is lower than that of Catamin AB. Sodium benzoate that has no oxidizing properties slows down the anodic dissolution of pipe steel in the active region only slightly (Fig. 8) and nearly does not affect the time to specimen fracture. The oxidizer, i.e., sodium $m$-nitrobenzoate, noticeably increases the time to fracture (from 189 to $256 \mathrm{~h}$ ). On the other hand, the RA value in the presence of benzoate increases to a higher extent (up to 48\%) than in the presence of $m$-nitrobenzoate $(\mathrm{RA}=39 \%)$. Apparently, a final conclusion on the ability of oxidants to efficiently prevent SCC of pipe steels cannot be made without additional studies.

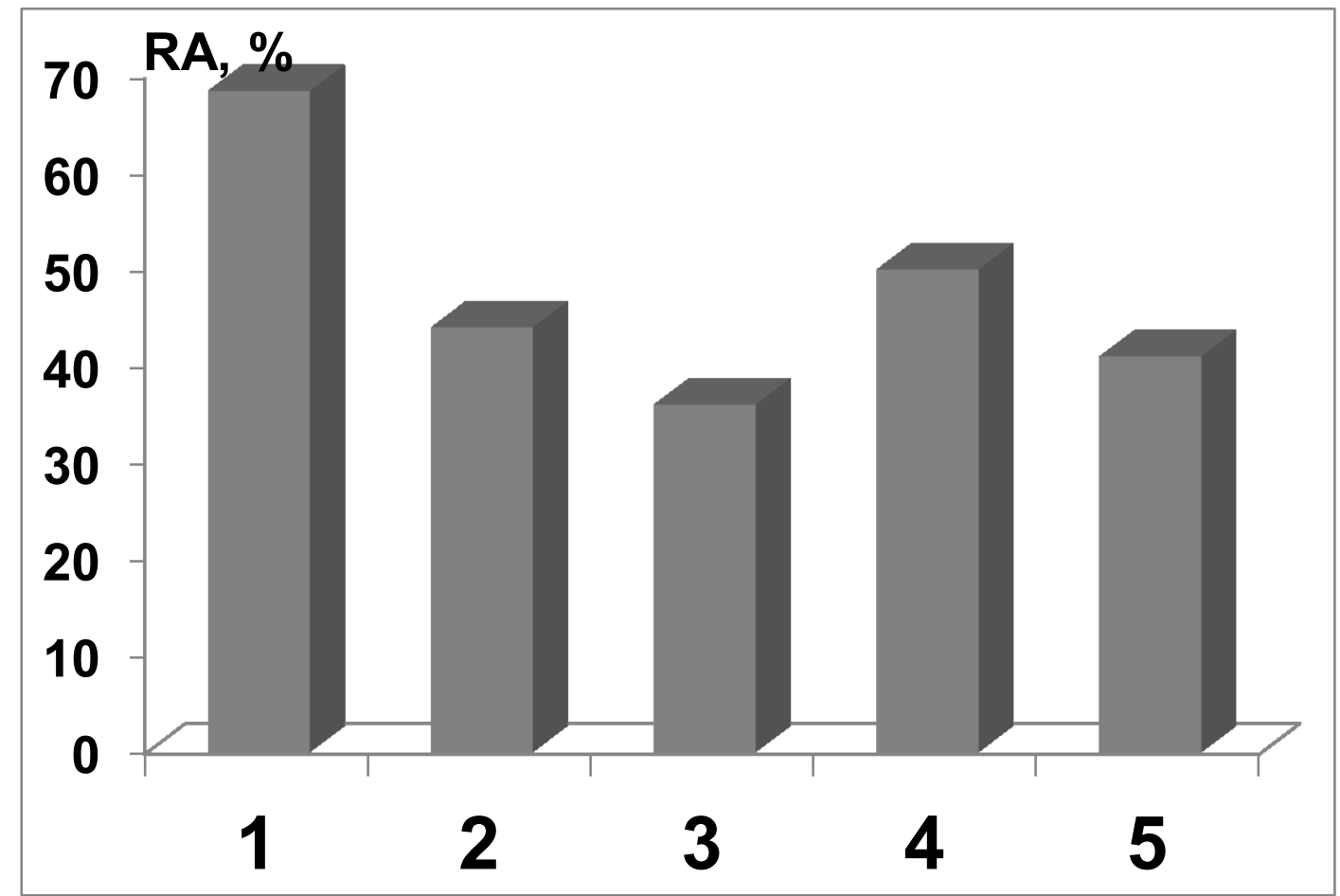

Fig. 13. Relative reduction of specimen area in air (1) and in solutions: NS4 in BB (2), NS4 in $\mathrm{BB}+10 \mathrm{mM} \mathrm{Na}_{2} \mathrm{~S}(3)$, NS4 in $\mathrm{BB}+10 \mathrm{mM} \mathrm{Na}_{2} \mathrm{~S}+0.5 \mathrm{~g} / \mathrm{L}$ benzoate (4), NS4 in BB + $10 \mathrm{mM} \mathrm{Na}_{2} \mathrm{~S}+1 \mathrm{~g} / \mathrm{L} m$-nitrobenzoate (5).

Comparison of the cracking resistance characteristics of pipe steels in the solutions studied shows that citrate buffer $(\mathrm{pH} 5.5)$ is a more corrosive environment than synthetic soil electrolyte NS4 with $\mathrm{pH} 6.5$ (both with and without borate buffer). The relative reduction of specimen area in CB $(26 \%)$ is smaller than that in NS4 $(60 \%)$ and NS4 + BB solutions (43\%). If hydrogen sulfide is present in the solutions, the difference between these test environments becomes more significant. In fact, the relative reduction of area in $\mathrm{CB}+10 \mathrm{mM} \mathrm{Na}_{2} \mathrm{~S}$ is as small as $11.6 \%$, i.e., nearly three times smaller than the value of $R=36 \%$ in the $\mathrm{NS} 4+\mathrm{BB}+10 \mathrm{mM} \mathrm{Na}_{2} \mathrm{~S}$ solution. The protective effect of corrosion inhibitors is evident in all the sulfide-containing media studied: Catamin $\mathrm{AB}$ increases the RA value 4.2-fold in CB and 2.1-fold in NS4 solution. 
Thus, a combination of electrochemical and corrosion-mechanical test results allows the conclusion to be made that it is principally possible to use inhibitors to protect pipe steel X70 from SCC. It appears most promising to perform subsequent studies with inhibitors of Catamin $\mathrm{AB}$ type, i.e., quaternary ammonium bases that showed a high protective effect in sulfide-containing media, while the presence of hydrogen sulfide in soil electrolytes is among the main factors that cause SCC of pipelines [6].

\section{Effect of potential on the plastic characteristics of X70 steel}

Figure 14 shows a plot of the relative reduction in specimen area $v s$. potential in an $\mathrm{NS} 4+1 \mathrm{mM} \mathrm{Na}_{2} \mathrm{~S}$ solution (curve 1 ). One can see that a relatively small negative shift in potential $(E=-0.6 \mathrm{~V})$ from the corrosion potential $(-0.42 \mathrm{~V})$ reduces the liability of pipe steel to SCC (RA increases to 63\%). This is apparently due to hindrance of the local anodic metal dissolution that inhibits the formation of primary stress concentrators (pits, etched grain boundaries) on the metal surface. The RA value decreases at more negative potentials. Under strong cathodic polarization $(E=-1.0 \mathrm{~V})$, it becomes smaller $(13 \%)$ than at the free corrosion potential. As shown in [18], a decrease in steel potential in a sulfidecontaining medium increases the amount of hydrogen that is incorporated into steel. As soon as some critical hydrogen concentration is reached in the metal, conditions for cracking by the hydrogen embrittlement mechanism arise in the metal. Hydrogen embrittlement becomes the predominant mechanism of pipe steel SCC under strong cathodic polarization $(E<-1.0 \mathrm{~V})$ in sulfide-containing media.

Anodic polarization of steel $(E=-0.4$ to $-0.3 \mathrm{~V})$ changes the RA value only slightly in comparison with that at the corrosion potential. This is explained by fast disappearance of the mechanic stress concentrators formed due to high dissolution rates of the entire metal surface. Hence, the applicability of SSRT for studies of steel SCC under conditions of intense active dissolution is limited. Anodic polarization tests of specimens with a preformed crack show that local metal dissolution is the predominant SCC mechanism in the vicinity of the corrosion potential [7].

Addition of $1.0 \mathrm{~g} / \mathrm{L}$ Catamin AB to NS4 solution increases the corrosion potential by $100 \mathrm{mV}$ (Fig. 14, curve 2). Under small cathodic polarization of a specimen $(E=-0.6 \mathrm{~V})$, RA in the inhibited solution reaches the maximum value of $67 \%$, i.e., it nearly coincides with the RA value obtained in steel tests in air (68\%). It should be noted that the RA value in the same solution but at the corrosion potential equals $60 \%$. Thus, combined protection should hinder pipe steel SCC to the maximum extent. 


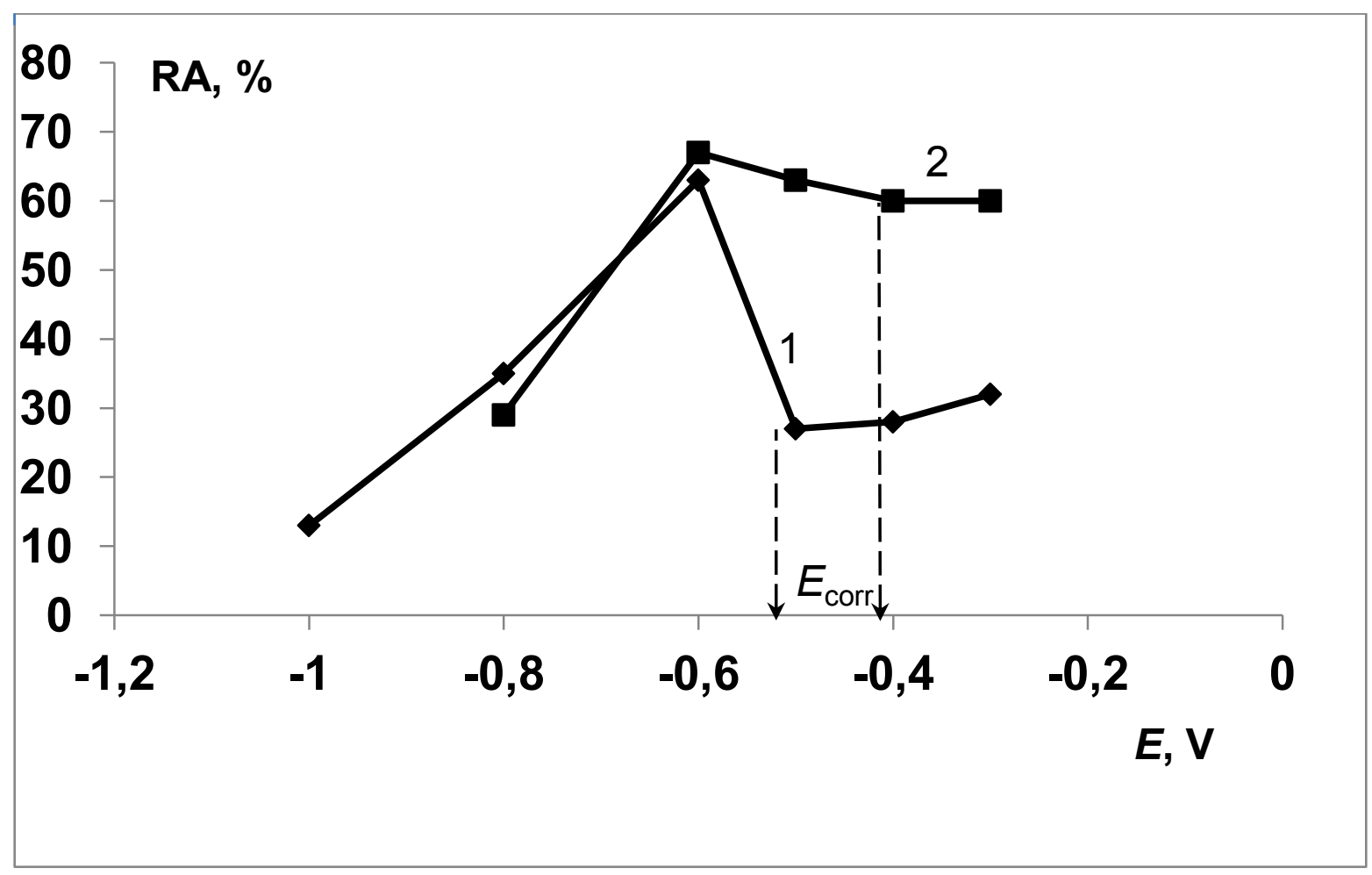

Fig. 14. Plot of relative reduction of specimen air versus potential in solutions: NS4 $+1 \mathrm{mM}$ $\mathrm{Na}_{2} \mathrm{~S}(1)$; NS4 $+1 \mathrm{mM} \mathrm{Na}_{2} \mathrm{~S}+1 \mathrm{~g} / \mathrm{L}$ Catamin $\mathrm{AB}(2)$.

\section{Conclusions}

1. The slow strain rate test (SSRT) has been used to study the effect of sodium sulfide, bicarbonate, and nitrate on the resistance of X70 pipe steel to stress corrosion cracking in weakly acidic citrate buffer ( $\mathrm{pH} 5.5)$ and in NS4 solution ( $\mathrm{pH}$ 6.5) simulating an electrolyte under delaminated coatings on underground pipelines. It has been shown that addition of sulfide and bicarbonate ions to the corrosive media stimulates SCC, whereas nitrate anions do not affect the cracking resistance of steel. Sulfide-containing solutions are the most corrosive test environments.

2. Comparison of the crack growth rates under static loading of pipe steel [7] with the characteristics of its cracking resistance obtained by SSRT shows that both methods give qualitatively similar results as regards the effect of soil (sub-film) electrolyte components on the liability of steel to SCC.

3. The anodic behavior of X70 pipe steel in NS4 solution in the presence of some organic corrosion inhibitors, namely, Catamin $\mathrm{AB}, 1,2,3$-benzotriazole, sodium benzoate and $\mathrm{m}$ nitrobenzoate, has been studied. It has been shown that addition of inhibitors to the solution results in considerable hindrance of pipe steel anodic dissolution.

4. It has been shown that corrosion inhibitors can considerably enhance the resistance of pipe steel to embrittlement in the media studied. 1,2,3-Benzotriazole and Catamin $\mathrm{AB}$ are the most efficient inhibitors of pipe steel SCC in sulfide-containing solutions.

5. The effect of potential on the cracking resistance of pipe steel in NS4 $+1 \mathrm{mM} \mathrm{Na}_{2} \mathrm{~S}$ solution has been studied. It has been shown that a small negative potential shift from 
the corrosion potential (up to $0.2 \mathrm{~V}$ ) hinders steel SCC. Hence, anodic metal dissolution is the main reason of crack growth at potentials in the vicinity of the corrosion potential. Hydrogen embrittlement of the metal becomes the predominant mechanism of pipe steel SCC only at a considerable negative potential shift $(E<-1.0 \mathrm{~V})$.

6. The cracking resistance of pipe steel at small cathodic polarization $(E=-0.6 \mathrm{~V})$ in inhibited $(1.0 \mathrm{~g} / \mathrm{L}$ Catamin AB) sulfide-containing NS4 solution is nearly the same as in the tests carried out in the air. Hence, pipe steel SCC can be efficiently prevented by combined inhibitor and electrochemical protection.

\section{References}

1. V. I. Nikitin, Fiz.-Khim. Mekh. Mater., 1989, 26, 47 (in Russian).

2. O. I. Steklov, Stoikost' materialov $i$ konstruktsii $k$ korrozii pod napryazheniem (Resistance of materials and structures to stress corrosion cracking), Moscow, Mashinostroenie, 1990 (in Russian).

3. F. Bolzoni, M. Cabrini, M. Caccia and M. Tarenzi, in: Progress in the understanding and prevention of corrosion, Cambridge, The University Press, 1993, Vol. 3, 1500.

4. B. W. Williams, S. B. Lambert, R. Sutherby and A. Plumtree, Corrosion, 2004, 60, 95.

5. J. A. Beavers, C. J. Maier, C. E. Jaske and R. Worthingham, Corrosion 2007, NACE International, paper 07128.

6. A. I. Malkin, A. I. Marshakov, V. E. Ignatenko and A. B. Arabei, Korroz.: mater., zashch., 2010, 2, 1 (in Russian).

7. R. N. Parkins, W. K. Blanchard and B. S. Delanty, Corrosion, 1994, 50, 94.

8. A. B. Arabei, R. I. Bogdanov, V. E. Ignatenko, A. Nenasheva and A. I. Marshakov, Fizikokhim. poverkhn. i zashch. mater., 2011, 47, 208 (in Russian).

9. M. Baker, Stress corrosion cracking study. Final report, OPS TTO8 Integrity Management Program, Department of Transportation, Office of Pipeline Safety, Calgary, Canada, 2005.

10. B. T. Lu and J. L. Lio, Environment-induced cracking of materials, 2008, 2, 24.

11. L. V. Frolova, E. V. Tomina, L. P. Kazansky and Yu. I. Kuznetsov, Korroz.: mater., zashch., 2007, 7, 22 (in Russian).

12. Yu. I. Kuznetsov and M. E. Garmanov, Elektrokhimiya, 1987, 23, 381 (in Russian).

13. I. L. Rozenfel'd, Yu. I. Kuznetsov, I. Ya. Kerbeleva and V. P. Persiantseva, Zashch. met., 1975, 10, 612 (in Russian).

14. Yu. I. Kuznetsov, L. P. Kazansky and A. A. Solomatin, Korroz.: mater., zashch., 2007, 10, 20 (in Russian).

15. N. P. Andreeva, Yu. I. Kuznetsov and M. O. Diyanova, Korroz.: mater., zashch., 2008, 3, 21 (in Russian).

16. V. E. Ignatenko, A. I. Marshakov, V. A. Marichev, Yu. N. Mikhailovsky and N. A. Petrov, Zashch. met., 2000, 36, 132 (in Russian). 